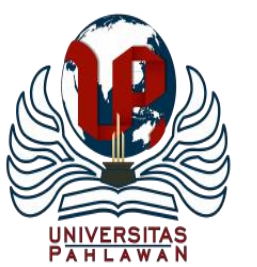

Jurnal Basicedu Volume 4 Nomor 2 April 2020 Hal. 505 - 512

JURNAL BASICEDU

Research \& Learning in Elementary Education

https://jbasic.org/index.php/basicedu

\title{
PENINGKATAN PEMBELAJARAN MATEMATIKA MELALUI STRATEGI BERBASIS MASALAH DI SEKOLAH DASAR
}

\author{
Dwi Wulan Suci ${ }^{1}$, Taufina ${ }^{2}$ \\ Sekolah Dasar Negeri 07 Pasaman, Sumatera Barat, Indonesia ${ }^{1}$ \\ Universitas Negeri Padang, Sumatera Barat, Indonesia ${ }^{2}$ \\ E-mail : : $\underline{\text { dwiwulansucim@gmail.com }}{ }^{1,} \underline{\text { taufina@ } @ \text { fip.unp.ac.id }}$
}

\begin{abstract}
Abstrak
Pengamatan dilaksanakan pada sebuah Sekolah Dasar di kota Padang, dengan mengamati pembelajaran matematika di kelas V, Saat membelajarkan matematika guru memperkenalkan siswa dengan rumus-rumus dalam pembelajaran matematika dan meminta siswa menyelesaikan masalah dari rumus-rumus yang telah disampaikan. Siswa diminta mengingat rumus dan konsep dalam pembelajaran matematika. Dalam hal ini guru memberikan langsung informasi kepada peserta didik. Siswa tidak dibiasakan dihadapkan pada pemecahan masalah matematika dalam pembelajaran tersebut. sehingga rumus, konsep yang didapatkan siswa penerapannya tidak begitu dirasakan siswa dalam kehidupannya sehari-hari. Sehingga peneliti tertarik untuk memperbaiki pembelajaran matematika tersebut, dengan menggunakan Strategi Pembelajaran Berbasis Masalah (SPBM) yaitu suatu strategi pembelajaran yang menghadapkan siswa pada permasalahan dalam kehidupan sehari-hari, yang dalam menyelesaikan masalah tersebut membutuhkan rumus dan konsep matematika, sehingga dapat menambah pengetahuan, keterampilan siswa menyelesaikan masalah dalam kehidupannya. Adapun langkah-langkah dalam SPBM antara lain : a) Memberikan permasalahan kepada siswa ,b) Mengorganisasikan siswa dalam pembelajaran guna untuk mengumpulkan data untuk menyelesaikan masalah, c) Membimbing siswa melakukan penyelesaian masalah, d) Menghasilkan karya berupa penyelesaian masalah, e) Analisis dan evaluasi hasil dan kinerja siswa. Setelah diambil data hasil tindakan pengamatan terhadap aktivitas guru dan siswa yang telah dilaksanakan, diperoleh hasil untuk aktivitas guru pada siklus 1 baik dan siklus 2 mencapai sangat baik. Sedangkan siswa siklus 1 baik dan siklus 2 sangat baik.
\end{abstract}

Kata Kunci: strategi, pembelajaran,berbasis masalah.

\begin{abstract}
Observations were held at an elementary school in the city of Padang, observing learning mathematics in class $\mathrm{V}$, When teaching mathematics the teacher introduces students to formulas in mathematics learning and asks students to solve problems from the formulas that have been submitted. Students are asked to remember formulas and concepts in learning mathematics. In this case the teacher provides information directly to students. Students are not accustomed to dealing with mathematical problem solving in learning. so that the formula, concepts obtained by students of application are not so felt by students in their daily lives. So that researchers are interested in improving mathematics learning, by using the Problem Based Learning Strategy (SPBM) which is a learning strategy that exposes students to problems in daily life, which in solving these problems requires mathematical formulas and concepts, so as to increase knowledge, skills students in solving problems in their lives. The steps in the SPBM include: a) Providing problems to students, b) Organizing students in learning in order to collect data to solve problems, c) Guiding students to solve problems, d) Producing work in the form of problem solving, e) Analysis and evaluating student results and performance. After taking data on the results of savings actions against teacher and student activities that have been carried out, the results obtained for teacher activities in cycle 1 are good and cycle 2 is very good. While students in cycle 1 are good and cycle 2 are very good.
\end{abstract}

Keywords: strategy, learning, problem based

@ Jurnal Basicedu 2020

$\triangle$ Corresponding author :

Address :-

Email : dwiwulansucim@gmail.com

Phone : 085263615123 


\section{PENDAHULUAN}

Matematika adalah ilmu yang dapat memancing keterampilan anak untuk berpikir kritis yang dapat diaplikasikannya untuk memecahkan masalah dalam kehidupannya yang berisi pemikiran abstrak, terdapat bilangan, simbol, rumus yang dipergunakan pada kegiatan berhitung (Edison, 2017). Pembelajaran matematika juga diharapkan dapat membantu anak untuk meningkatkan cara berpikirnya dalam memecahkan masalah, penalaran dan permainan logika (Taufina, Chandra, Fauzan, \& Ilham Syarif, 2019)

Pembelajaran matematika seharusnya tidak menjadi hal yang ditakuti oleh siswa, karena matematika adalah ilmu yang mengandung simbol, rumus, konsep yang sangat berguna dalam kehidupan. Seharusnya rumus, simbol dan konsep tersebut berguna dalam memecahkan masalah dalam kehidupan siswa yang untuk mengatasinya menggunakan hal tersebut. didalam matematika banyak model-model yang dapat membantu siswa membentuk pola pemikiran yang matematika yang sistematika, dapat membantu siswa berfikir logis dan kritis, yang membutuhkan kecermatan (Zaini \& Marsigit, 2014)

Banyak sekali permasalahan dalam berbagai aspek kehidupan yang pemecahannya memerlukan matematika. Oleh sebab itu, maka sangat perlu rancangan pembelajaran matematika yang dapat membantu siswa dalam mengaplikasikan ilmu yang didapatkan untuk memecahkan masalah dalam kehidupannya. Sehingga memberi rasa puas kepada siswa bahwa ilmu yang didapatkannya benar-benar bermanfaat untuk kehidupannya (Karmawati, 2009:1)

Menyelesaikan masalah pada pembelajaran matematika, perlu pemahaman konsep yang jelas oleh siswa, untuk memecahkan masalah seperti apasajakah yang dapat diselesaikan dengan konsep yang didapatkan. Di sini peran guru sangat dituntut dalam pemahaman konsep matematika. Guru harus menyajikan mata pelajaran matematika agar siswa merasakan manfaat dia mempelajari hal tersebut untuk kehidupannya. Guru diharapkan menguasai model, strategi pembelajaran matematika yang dapat membantu siswa dalam pembelajaran, dapat melatih siswa mengembangkan penelaran berfikirnya dalam matematika. Guru harus membuat pembelajaran yang berkesan, berbekas pada peserta didik (Diah Ayu Indraningtias \& Wijaya, 2017).

Sehingga ketika dia dihadapkan pada permasalahan dalam kehidupan sehari-hari yang bervariasi, siswa tidak kewalahan mengerjakannya. Sehingga pembelajaran matematika tidak menjadi suatu hal yang seharusnya ditakuti siswa. Iklim belajar yang diciptakan guru harus juga kondusif agar siswa lebih termotivasi. Disamping itu, tingkat perkembangan anak juga perlu menjadi perhatian guru, sehingga pemberian masalahnya juga sesuai dengan tingkat pemikirannya (Muslimin, dkk: 2012)

Kompetensi siswa dalam memecahkan masalah matematika dalam kehidupan sehari-hari masih jauh dari yang diharapkan, ketika siswa diberikan soal pemecahan masalah yang meminta siswa berpikir kritis dengan melibatkan pemikiran dan penalarannya, siswa masih terlihat kesulitan (Fauzan \& Yerizon, 2013)

Siswa Sekolah Dasar (SD) tingkat pemikirannya masih pada tingkat operasional konkrit, pembelajaran masih menggunakan bendabenda nyata yang membantu sebagai media pembelajaran (Desi Indriyani1, Desyandri2, Yanti Fitria3, 2019)

Siswa kelas rendah (kelas1, 2,3) masih sulit memahami konsep perkalian, pembagian persen. 
Pada perkalian, siswa sekolah dasar harus dimulai dari konsep sebelumnya mengenai penjumlahan, terlebih dahulu siswa harus paham dengan baik konsep penjumlahan agar dapat lanjut ke perkalian. Siswa harus memahami terlebih dahulu permasalahan-permasalahan dalam kehidupannya yang dapat dia selesaikan dengan konsep penjumlahan tersebut. sementara kelas tinggi ( IV,V,VI) sudah mulai berfikir secara deduktif, sudah dapat mengembangkan logika dan penalaran. Oleh sebab itu guru harus merancang strategi pembelajaran yang tepat agar siswa dapat menggunakan logika dan penalarannya tersebut untuk kehidupannya, hendaknya dia merasakan bahwa pembelajarannya memang benar-benar bermakna dan dapat diterapkannya dalam kehidupannya (Mewa, dkk:2015)

Masalah dalam pembelajaran matematika tersebut dapat disebabkan karena pendekatan yang digunakan sangat teoritis, kurang memperhatikan dari segi penalaran, logika sehingga matematika menjadi sesuatu yang terasa sulit dan menakutkan (Fauzan, Slettenhaar, \& Plomp, 2002).

Secara tidak langsung, strategi yang dilakukan dengan tindakan yang tepat dapat mempengaruhi terhadap hasil belajar siswa. Proses pembelajaran yang efektif berbanding lurus dengan hasil yang didapatkan (Fauzan et al., 2002)

Sebuah proses yang direncanakan dan dilaksanakan dengan matang akan dapat dilihat dari hasil yang diperoleh. Jika kurang maksimal hasil yang didapat, maka dapat ditinjau kembali proses dapat dilakukan refleksi terhadap rencana dan kegiatan pelaksanaannya. Apakah model, pendekatan dan strategi yang digunakan cocok untuk mengatasi permasalahan tersebut (Wina, 2008:2).

Dari hasil pengamatan aktivitas guru dan siswa dalam pembelajaran matematika di kelas $\mathrm{V}$ sebuah sekolah dasar, ketika terjadi proses pembelajaran, mengenai materi perkalian pecahan, guru mengajarkan kepada siswa bahwa untuk mencari hasil perkalian tersebut, siswa langsung mengalikan pembilang dikalikan dengan pembilang dan penyebut dikalikan dengan penyebut. Kemudian siswa diberikan soal-soal latihan, setelah itu guru mengajarkan konsep pembagian. Siswa diminta menghapal cara yang diajarkan guru dan mengingat informasi yang disampaikan guru. Setelah selesai pembelajaran, guru memeriksa latihan siswa, dari hasil yang diperoleh, dari 25 orang siswa, 22 orang mendapatkan nilai diatas 70. Dan dikatakan tuntas. Karena Kriteria Ketuntasan Yang ditetapkan untuk indicator tersebut adalah 70. Setelah itu guru memberikan permasalahan kepada siswa berupa soal cerita yaitu Ibu ingin memasak 2 bungkus agar-agar. Agar-agar yang telah dimasak tersebut akan dimasukkan ke dalam cetakan. Masingmasing cetakan berisi ${ }^{\frac{2}{3}}$ bungkus agar-agar. Berapa buah cetakan yang diperlukan untuk mencetak agar-agar ibu tersebut?. Dalam menyelesaikan permasalahan tersebut, siswa tidak tahu bagaimana dan menggunakan cara apa untuk menyelesaikannya. Hal tersebut dikarenakan mereka tidak mengetahui dengan pasti gambaran besar masalah. Namun, siswa takut untuk bertanya bahkan cenderung tidak tahu apa yang akan ditanyakan. Sehingga menyebabkan siswa tidak dapat mengaplikasikan konsep yang didapat tadi untuk menyelesaikan soal tersebut.

Dari permasalahan yang telah peneliti sampaikan tersebut, sehingga peneliti berkeinginan melakukan perbaikan proses pembelajaran dengan enggunakan Strategi Pembelajaran Berbasis Masalah (SPBM) dalam pembelajaran matematika tersebut. SPBM merupakan strategi Pembelajaran yang menggunakan masalah dalam kehidupan sehari-hari sebagai konteks dalam pembelajaran siswa, siswa belajar matematika di mulai dari masalah (Sahat Saragih, 2004) 
508 Peningkatan pembelajaran matematika melalui strategi berbasis masalah di sekolah dasar-Dwi Wulan Suci, Taufina

Siswa dituntut untuk dapat menyelesaikan masalah dalam kehidupan sehari-harinya secara sistematis. Mengembangkan kemampuannya dalam berlogika dan bernalar (Ilma \& Putri, 2010).

Dari proses menemukan solusi tersebut siswa mengembangkan segala kemampuan dan potensi dirinya, mulai dari memahami permasalahan, menemukan alternative penyelesaian masalah, mencobakan alternative, menemukan rumus, cara dan konsep pembelajaran. Dan menarik kesimpulan serta mempresentasikan solusi menyelesaikan persoalan tersebut. SPBM juga strategi pembelajaran yang menggunakan situasi real atau nyata sebagai media untuk siswa belajar matematika. Dari masalah lah siswa menemukan konsep, rumus, informasi yang ingin dicapai dalam pelajaran matematika (Nurhadi, 2003:55).

Berdasarkan yang telah peneliti sampaikan sebelumnya, peneliti mencoba merancang Bagaimanakah pelaksanaan SPBM dapat membantu meningkatkan pembelajaran matematika di sekolah dasar. Bagaimanakah rencana pelaksanaan pembelajaran yang menggunakan strategi pembelajaran berbasis masalah tersebut?

\section{METODE}

Pendekatan, metode dan cara pengumpulan data yang peneliti lakukan di sini secara kualitatif, berupa melakukan pengamatan pembelajaran, observasi, wawancara dengan penelitian tindakan kelas. Sesuai dengan tujuannya tindakan dilakukan untuk meningkatkan proses pembelajaran. Yang dilakukan dikelas yang digolongkan kepada penelitian partisipan karena peneliti langsung terjun ke lapangan melakukan tindakan tersebut (Suharsimi, 2006:3)

Kegiatan yang dilakukan peneliti diawal kegiatan adalah memberikan soal tes kepada siswa hal tersebut dilakukan oleh peneliti untuk membantu peneliti membagi kelompok pada proses pembelajaran nanti, peneliti memberikan soal berupa masalah kepada masing-masing siswa, dan meminta mereka menyelesaikan masalah tersebut dengan caranya sendiri-sendiri. Peneliti ingin mengetahui cara berfikir masing-masing siswa dari kegiatan tersebut Setelah kegiatan tersebut peneliti menyusun kelompok berdasarkan hasil tes yang telah dilaksanakan siswa. Dari persamalahan yang telah disampaikan peneliti melakukan diskusi dengan guru kelas mengenai usaha yang dapat dilakukan dalam pembelajaran matematika tersebut. Tindakan direncanakan dengan langkah-langkah membuat perencanaan pembelajaran, melaksanakan pembelajaran, melakukan pengamatan terhadap proses pembelajaran dan diakhiri dengan melakukan refleksi terhhadap tindakan yang telah dilaksanakan (Ilma \& Putri, 2010)

Pada tahap perencanaan tindakan peneliti merancang sebuah renca pelaksanaan pembelajaran yang berisi langkah-langkah kegiatan yang akan dilaksanakan siswa yang sesuai dengan SPBM yang digunakan guru. Rencana pembelajaran disusun dengan mempertimbangkan aspek perkembangan siswa.(Rahmawati, 2013)

Peneliti memikirkan masalah yang diberikan sesuai dengan taraf berfikir siswa kelas 5 sekolah dasar. Dalam rancangan tersebut peneliti menentukan standar dan Kompetensi dasar apa yang ingin dicapai, menentukan indicator dan tujuan pembelajaran, dan menetapkan kegiatan guru dan siswa yang sesuai dengan SPBM, menentukan media, model-model,alat peraga yang mendukung pencapaian tujuan pembelajaran. Terakhir guru menentukan alat evaluasi yang digunakan mengukur pencapaian anak pada Kompetensi yang diminta. Dalam perencanaan, peneliti juga menyiapkan instrumen yang digunakan guru untuk melakukan wawancara, 
observasi untuk melihat pelaksanaan tindakan yang dilakukan (Soedjadi, 2014).

Setelah tahap perencanaan, penneliti melaksanakan tindakan. Dallam tahap pelaksanaan tindakan, peneliti langsung sebagai pelaksana atau guru. Peneliti melaksanakan pembelajaran sesuai dengan rancangan yang telah dibuat. Pada perencanaan, peneliti merancang kegiatan yang dilakukan sebanyak dua tahap atau siklus. Pada siklus pertama peneliti melaksanakan pembelajaran sebanyak dua kali pertemuan. Materi pada pertemuan satu yaitu mengalikan dua buah pecahan dan pertemuan dua mengalikan bilangan asli dengan pecahan. Sedangkan siklus dua juga dilaksanakan duua kali pertemuan. Pertemuan satu membagi dua buah pecahan dan pertemuan dua membagi bilangan asli dengan pecahan.

Dalam kegiatan pelaksanaan ini peneliti sebagai alat atau instrument penelitian. Bersamaan dengan kegiatan pelaksanaan dilaksanakan juga kegiatan pengamatan. Peneliti meminta guru melakukan pengamatan dan mengisi lembar pengamatan yang telah disediakan. Observer melakukan pengamatan dan kegiatan mendokumentasikan kegiatan pembelajaran yang dilakukan, mengamati aktivitas guru dan siswa dalam proses pembelajaran.

Setelah proses pembelajaran diamati peneliti dan observer melakukan tahap refleksi berupa mengkaji kembali kegiatan yang telah dilaksanakan. Mengkaji kelebihan yang bias dipertahankan dan kekurangan-kekurangan yang ada baik dalam rancangan dan pelaksanaan. Dan menganalisis hasil pengamatan yang telah dilakukan. Setelah didapatkan, peneliti kembali merancang kegiatan yang akan dilakukan untuk siklus berikutnya. Tahap tersebut dilakukan peneliti secara berulang mulai dari tahap perencanaan, pelaksanaan, pengamatan dan refleksi sampai pada hasil yang dianggap peneliti sudah memuaskan dan maksimal. Jika hasil yang maksimal rasanya sudah didapatkan peneliti, maka penelitian sudah berakhir di siklus tersebut.

\section{HASIL DAN PEMBAHASAN}

Pembelajaran yang dilaksanakan pada siklus satu pertemuan satu dengan materi pembelajaran yaitu melakukan perkalian dua buuah pecahan. Pada tahap perencanaan guru menyusun Rencana Pelaksanaan Pembelajaran (RPP) tentang perkalian dua pecahan. Menyusun kegiatan pembelajaran yang sesuai dengan langkah-langkah pembelajaran SPBM. Membuat Lembar Kerja Peserta Didik (LKPD). Dan menyiapkan instrument evaluasi diakhir pembelajaran. Di samping itu pada tahap perencanaan ini, guru membuat instrumen pengamatan RPP, langkah kegiatan guna mengumpulkan informasi dalam proses pembelajaran nantinya. Kemudian instrument pengamatan aktivitas yang dilakukan oleh guru dan oleh siswa.

Setelah semua instrument yang dibutuhkan lengkap dalam tahap perencanaan barulah peneliti melaksanakan tindakan sesuai dengan perencanaan yang telah dibuat. Pada tahap pelaksanaan ini peneliti melaksanakan kegiatan proses pembelajaran dan guru kelas melaksanakan pengamatan terhadap proses yang dilakukan. Peneliti bertindak sebagai guru melaksannakan kegiatan sesuai langkah-langkah yang tertuuang dalam perencanaan. Dalam pelaksanaan guru melakukan bimbingan kepada siswa.

Kegiatan pembelajaran dengan SPBM ini dimulai dengan guru memberikan masalah berbentuk soal cerita yang benar-benar ditemuinya adalam kehidupan sehari-hari. Kemudian guru meminta siswa mendiskusikan permasalahan yang telah diberikan guru dalam kelompok yang sudah dibagi. Masing-masing kelompok dibimbing menemukan informasi yang terdapat dalam permasalahan tersebut. mulai dari menemukan apa 
yang dapat diketahui oleh siswa di dalam soal, appa yang ditanya kan dalam soal.

Setelah siswa memahami soal dengan seksama, guru membimbing dan mengarahkan siswa untuk melakukan penyelidikan apa teori untuk menyelesaikan masalah tersebut. meminta siswa memikirkan berbagai cara dengan memberikan pertanyaan pertanyaan. Siswa mencoba menyelesaikan permasalahan dengan menggunakan model-model, alat peraga konkrit yang telah disediakan. Dalam menyelesaikan masalah, siswa menciptakan suasana seperti yang diceritakan dalam permasalahan.

Guru kemudian menanyakan kepada siswa bagaimana cara mencari panjang pita kakak seluruhnya. Sesuai langkah-langkah yang terdapat dalam LKPD, siswa menandai panjang masing pita kakak kemudian menggunting panjang masingmasing pita kakak. Untuk mencari panjang seluruh pita kakak siswa melekatkan panjang masing masing pita kakak kemudian mengukur panjang seluruh pita kakak. Dengan kegiatan tersebut siswa mendapatkan panjang seluruh pita kakak.

Setelah siswa melakukan kegiatan penyelidikan, siswa mengemukakan cara untuk menyelesaikan permasalahan bersama kelompok. Setelah itu. Siswa menyampaikan gagasannya bersama kelompok lain. Semua kelompok menyampaikan cara yang dilakukan untuk menyelesaikan masalah. Semua cara dirangkum dan diambil kesimpulan bagaimana cara yang biasa dilakukan untuk menyelesaikan masalah. Dari hal tersebut, semua proses pembelajaran dilakukan sepenuhnya oleh siswa, guru hanya sebagai fasilitator yang mengarahkan siswa menemukan cara yang tepat menyelesaikan masalah.

Bersamaan dengan proses pembelajaran yang dilakukan, observer menjalankan tugasnya mengamati kegiatan guru dan siswa selama pembelajaran dengan mengisi instrument yang telah disediakan. Mencatat apa yang ditemui dalam proses pembelajaran. Observer mengisi daftar lembar pengamatan yang telah disediakan dengan memberikan tanda centang pada lembar pengamatan tersebut, sesuai dengan kenyataan yang dilihatnya.

Dari hasil pengamatannya tersebut didapatkanlah hasil baik pada aktivitas siswa dan guru pada siklus satu pertemuan satu. Hasil tersebut didapatkan dengan perhitungan

$$
\frac{\text { jumlahskoryangdiperoleh }}{\text { jumlahskomaksimal }} \times 100 \%
$$

Pengamatan terhadap kegiatan guru dan siswa yang dilakukan pada pembelajaran antara lain peneliti mengkondiskan kelas dengan baik, meminta siswa berdoa serta mencek kehadiran siswa, dalam berdoa dan mengambil absen siswa terlihat kurang serius melakukan kegiatan tersebut banyak siswa terlihat masih bergelut dengan teman nya. Kemudian guru mengingatkan siswa pada operasi perkalian dua pecahan dengan memberikan 1 buah soal isian kepada siswa dipapan tulis

Pada langkah meminta siswa menganalisis masalah yang diberikan, guru kurang memotivasi siswa, sehingga masih ada bebrapa siswa yang kurang antusias atau berminat terhadap soal yang diberikan. Terlihat dari siswa tidak aktif menjawab pertanyaan guru. Namun sebagian ada yang terlihat sangat tertarik sehingga merespon setiap pertanyaan yang diajukan guru.

Pada langkah pengujian, terlihat aktivitas dan ketelitian siswa dalam menemukan cara menyelesaikan masalah. Ada beberapa kelompok yang salah dalam menggunting pita, sehingga mereka harus melekatkan kembali pitta tersebut. dan guru tampak membimbing lebih kelompok yang mengalami kesulitan.

Sambil melakukan kegiatan, siswa juga dibimbing mengisi LKPD. Dalam pengisian ada sebagiian siswa yang tidak mau ikut serta, hal 
tersebut terlihat ketika guru bertanya tentang isi lembar kerja kelompok tersebut, ada sebagian yang tidak tahu apa isi LKPD nya tersebut. guru memotivasinya untuk ikut aktif di dalam kelompok ketika mengisi dan mengikuti setiap langkah dalam LKPD.

Pada langkah yang tetrakhir, siswa melaporkan hasil diskusinya kke depan kelas. Masing-masing kelompok memberikan tanggapannya terhadap hasil diskusi kelompok lain. Dan bersama mengambil kesimpulan. Dalam kegiatan ini, belum berjalan secara maksimal, karena masih sedikit siswa yang memberikan tanggapan dalam kegiatan diskusi.

Setelah seluruh langkah SPBM terlaksana, guru memberikan beberapa latihan soal, secara individu yang penyelesaiannya menggunakan perkalian dua buah pecahan. Dari kegiatan tersebut juga dipperoleh keberhasilan tindakan yang dilakukan guru mencapai $73,44 \%$. Dilihat dari skor yang diperoleh guru dalam lembar pengamatan.

Kemudian tindakan dilanjutkan dengan pertemuan kedua seperti langkah-langkah yang telah dilakukan pada pertemuan kesatu dengan materi yang berlanjut yaitu perkalian pecahan biasa dengan campuran. Pada pertemuan kedua guru mulai meningkatkan kekurangan kekurangan yang ada pada pertemuan sebelumnya.

Sebelum memberikan permasalahan, guru memotivasi siswa dengan memberikan cerita yang dapat memancing siswa untuk lebih tertarik dalam belajar. Baru kemudian guru mengaitkan cerita dengan memberikan permasalahan yang nantinya akan diselesaikan dengan matematika. Dalam pertemuan kedua ini tampak siswa mulai tergerak untuk bekerja. Ketika siswa mengerjakan lembar kerja siswa, terlihat hampir semua siswa ikut bekerja. Sehingga skor pengamatan kegiatan siswa dan guru pada lembar pengamatan mengalami peningkatan dari pertemuan sebelumnya.
Peneliti sebagai partisipan merasa belum maksimal Dalam melakukan tindakan, sehingga peneliti melanjutkan tindakan ke siklus kedua yang direncannakan juga sebanyak dua kali pertemuan. Hanya saja materi yang diberikan masih berlanjut pada materi sebelumnya. Yaitu membagi pecahan dengan pecahan. Langkah yang digunakan tidak begitu berbeda jauh dengan pada sklus satu, pada siklus kedua peneliti sedikit menambahkan langkah yang lebih sistematis pada LKPD yang akan dikerjakan kelompok.

Setelah mengkondisikkan kelas, guru kembali memberikan permasalahan yang berhubungan dengan pembagian dua buah pecahan, guru tak lupa memberikan siswa motivasi untuk menyelesaikan permasalahan. Langkahlangkah pembelajaran sama dengan pada siklus satu, pada siklus guru lebih meningkatkan memotivasi anak, setelah anak mencoba menyelesaikan masalah dengan tema yang berbeda, siswa mulai terbiasa berpikir kritis dan menganalisis permasalahan tersebut, siswa mulai terbiasa meningkatkan penalaran dan logikanya dalam menyelesaikan masalah. Terlihat dari hasil pengamatan yang diperoleh dalam siklus dua untuk aktivitas guru dan siswa memperoleh predikat sangat baik.

\section{SIMPULAN}

Setelah membahas pembelajaran menggunakan Strategi Pembelajaran Berbasis Masalah (SPBM) maka dapat disimpulkan bahwa strategi yang digunakan tersebut dapat meningkatkan pembelajaran matematika pada siswa kelas V sekolah dasar, dengan menggunakan langkah memberikan permasalahan, menganalisis masalah, melakukan pembimbingan penyelidikan masalah, mengumpulkan data dan informasi, serta menganalisis dan mmengevaluasi kegiatan yang telah dilakukan. Pembelajaran yang dilakukan sebanyak dua siklus tersebut meningkatkan 
512 Peningkatan pembelajaran matematika melalui strategi berbasis masalah di sekolah dasar-Dwi Wulan Suci, Taufina

aktivitas dari guru dan siswa, pada siklus satu aktivitas guru dan siswa memperoleh predikat baik, setelah dilakukan perbaikan tindakan pada siklus dua meningkat menjadi sangat baik. Dari hasil wawancara dengan siswa, pembelajaran dengan menggunakan SPBM dapat menarik keinginan siswa untuk belajar. Siswa menjadi lebih termotivasi dan tertantang menyelesaikan masalah tersebut.

\section{DAFTAR PUSTAKA}

Desi Indriyani1, Desyandri2, Yanti Fitria3, I. (2019). Jurnal basicedu. Jurnal Basicedu, $3(2), 524-532$.

Diah Ayu Indraningtias, A., \& Wijaya, R. (2017). Pengembangan Perangkat Pembelajaran Berbasis Pendekatan Matematika Realistik Materi Bangun Ruang Sisi Datar Berorientasi Pada Kemampuan Berpikir Kritis Siswa. Jurnal Pendidikan Matematika, 6(5), 24-36. Retrieved from perangkat pembelajaran, pendekatan matematika realistik, kemampuan berpikir kritis.

Edison. (2017). Jurnal basicedu. Jurnal Basicedu, $1(2), 59-65$.

Fauzan, A., Slettenhaar, D., \& Plomp, T. (2002). Teaching Mathematics in Indonesian Primary Schools Using Realistic Mathematics Education (RME)-Approach. The Second International Conference on the Teaching of Mathematics at the Undergraduate Level, 16.

Fauzan, A., \& Yerizon. (2013). Pengaruh Pendekatan RME dan Kemandirian Belajar Terhadap Kemamampuan Matematis Siswa. Prosiding Semirata FMIPA Universitas Lampung, 7-14.

Ilma, R., \& Putri, I. (2010). Desain Bahan Ajar Penjumlahan Pecahan Berbasis Pendidikan Matematika Realistik Indonesia ( PMRI ) Untuk Siswa Kelas IV Sekolah Dasar Negeri 23 Indralaya. Jurnal Pendidikan Matematika, 4(2), 86-96.

Karmawati, 2009. Inovasi Pembelajaran Matematika Sekolah Dasar. Jurnal kreano. Vol 4 no 3. Tahun 2017

Mewa, dkk. 2015. Desain Pembelajaran Materi Pecahan MenggunakanPendekatan PMRI di
Kelas V. Jurnal Beta Vol. 8 No. 1 (Mei) 2015 ,

Muslimin, dkk. 2012. Desain Pembelajaran Pengurangan Bilangan Bulat Melalui Permainan Tradisional Congklak Berbasis Pendidikan Matematika Realistik Indonesia di Kelas IV Sekolah Dasar: Jurnal F MIPA UNNES vol 3 no 2

Rahmawati, F. (2013). Pengaruh Pendekatan Pendidikan Realistik Matematika dalam Meningkatkan Kemampuan Komunikasi Matematis Siswa Sekolah Dasar. Prosiding SEMIRATA 2013, 1(1), 225-238. Retrieved from

http://jurnal.fmipa.unila.ac.id/index.php/semi rata/article/view/882

Sahat Saragih. (2004). Menumbuhkembangkan Berpikir Logis dan Sikap Positif terhadap Matematika melalui Pendekatan Matematika Realistik Sahat Saragih. Jurnal Pendidikan Dan Kebudayaan Departemen Pendidikan Nasional. Badan Penelitian Dan Pengembangan, (1589). Retrieved from https://www.researchgate.net/profile/Sahat_S aragih/publication/255671760_Menumbuhke mbangkan_Berpikir_Logis_dan_Sikap_Positi f_terhadap_Matematika_melalui_Pendekatan _Matematika_Realistik/links/58b7c70caca27 261e51aab3c/MenumbuhkembangkanBerpikir-Logis-dan-S

Soedjadi, R. (2014). Inti Dasar - Dasar Pendidikan Matematika Realistik Indonesia. Jurnal Pendidikan Matematika, 1(2), 1-10. https://doi.org/10.22342/jpm.1.2.807.

Taufina, T., Chandra, C., Fauzan, A., \& Ilham Syarif, M. (2019). Development of Statistics in Elementary School Based RME Approach with Problem Solving for Revolution Industry 4.0. 382(Icet), 716-721.

Zaini, A., \& Marsigit, M. (2014). Perbandingan Keefektifan Pembelajaran Matematika Dengan Pendekatan Matematika Realistik Dan Konvensional Ditinjau Dari Kemampuan Penalaran Dan Komunikasi Matematik Siswa. Jurnal Riset Pendidikan Matematika, 1(2), 152. https://doi.org/10.21831/jrpm.v1i2.2672

Wina, Sanjaya. 2008. Strategi Pembelajaran Berorientasi Standar Proses Pendidikan. Jakarta: Prenada Media Group. Jurnal Pendidikan Matematika, 1(2), 112-119. 